\title{
Factors Influencing Human Resource Planning (HRP) for Local Workforce Supply in Malaysian Construction Industry
}

\author{
Norhidayah Md Dom ${ }^{1}$, Narimah Kasim² ${ }^{2}$ and Alina Shamsudin ${ }^{3}$ \\ Received September 26, 2011 / Revised February 2, 2012 / Accepted February 6, 2012
}

\begin{abstract}
The lacks of local workforce supply become a problematic in Malaysian construction industry. Meanwhile, HRP is important during workforce supply to help organizations in order to appoint the right people in the right job. This paper reports on the use of factors influencing HRP towards local workforce supply in the construction industry in general, and Malaysian construction in particular. Semi structured interviews were conducted to 10 interviewees from the government and non-government organizations to investigate current issues of local workforce and the practices of HRP in the construction organization. The analysis methods were based on descriptions of previous tested research. The findings reveal that the lack of local workforce is due to low wages system, safety issues, educational changes, low status and unsecured work, environment in construction industry, developments and technologies changes in Malaysia. The internal factors of HRP were practiced among construction organization are organization strategy, organizational culture, organization changes, leadership and experience, nature of work and empowerment of labor. Meanwhile, the external factors are technology changes, economic changes, legislation and demographic changes. The paper provides valuable information on the practices of factors influencing HRP for local workforce supply in Malaysian construction industry.
\end{abstract}

Keywords: Construction industry, Human resource planning, Factors influencing HRP, Local Workforce, Malaysia

\section{INTRODUCTION}

Human Resource Planning (HRP) is a common concept in management theory [1]. It has been practiced in many fields such as business [2], engineering [3], medicine [4] and science [5]. Being a common concept in management, as a corollary, it can practically be implemented in the construction workforces particularly in Malaysia. Construction workforces in Malaysia have shown the lack of local workforce participation, as a result the abundance of foreign workers employs in construction industry [6]. In context of this study, local workforce is referred to general worker (labor); which performed for construction activities such as bricklaying; plastering; tiling, bar-bending; concreting and formwork. The findings from previous research show that local workforce performance in construction industry has resulted in the urgent need for the Malaysian construction industry to face current and future challenges [7].

There are currently a variety of approaches which are used to overcome local workforce issues such as: provide skill training, testing and certification; provide a safe and health work environment; upgrading the construction operation; paying competitive wages and benefits; and provide good working conditions to them [8][9]. However, HRP is mostly ignored in HR in most organizations because those at the top management do not know the value of HRP [10].
It is having possibility that the lacks of local workforce participation due to a paucity of positive examples of where such tools have been used successfully in HRP.

HRP seen as a process that focuses on human resource need under varying conditions and develop the essential initiatives to satisfy human resource needs [11]. It provides practical and advance tools for contractors to predict the reasonable labor required for construction project [12]. In Hong Kong, HRP factors have a long-run equilibrium effect to determine the local construction manpower supply by identified the internal (construction output; real wages; material price; bank rate; and labor productivity) and external (technology, utilization capacity and various mix of work) of HRP influencing factors [12]. The internal and external factors of HRP are not only creating, but also shape and change the issues and workforce numbers in the future [12][13]. In addition, a strong analysis of internal and external factors is a significantly approach have been used to ensure the successfully of HRP [14]. The study in which construction industry-wide practices with respect to the factors influencing HRP for local workforce supply was clearly described, highlighted the significant implementation that exist for HRP in construction.

\footnotetext{
${ }^{1}$ M.S. Student, Universiti Tun Hussein Onn Malaysia, Parit Raja, Batu Pahat, Johor, ayudayahaida@ gmail.com (*Corresponding Author)

${ }^{2}$ Senior Lecturer, Universiti Tun Hussein Onn Malaysia, Parit Raja, Batu Pahat, Johor, narimah@uthm.edu.my

${ }^{3}$ Senior Lecturer, Universiti Tun Hussein Onn Malaysia, Parit Raja, Batu Pahat, Johor, alina@uthm.edu.my
} 
Incontrovertibly, given the uniqueness that HRP is a rigid system that must be implemented for local workforce supply in Malaysian construction industry. Therefore, in order to address HRP in Malaysian construction industry awareness relative to what issues of local workforce and possible factors influencing HRP should be inculcated into the minds of construction managerial.

\section{WORKFORCE ISSUES}

Workforce is a number of workers available to complete activity, job or project in the scopes of work [15]. In particular, the construction industry places heavy reliance upon the skills of its workforce [16]. Accordingly, the construction industry in Malaysia is highly reliance on workforce energy to provide the construction industry operations [9]. The country expects majority of the construction tasks should be carried out by local workforce [17]. However, foreign workers are imported to perform the jobs that Malaysian refuses to do [6]. The uses of foreign workers are still necessary in wet trade work such as bricklaying; plastering; tiling; bar-bending; concreting; and formwork therefore; efforts need to minimize them before they are dominant in Malaysian construction industry [8]. Government noticed to all companies and employers not make excuses for hired foreign workers until it would obstruct our local labor chances [17]. Employers are required being fair to the local workforce by offered reasonable and attractive salaries.

Workforce analysis begins with focuses into issue which highlights the future workforce requirements needed up front and determine the current and future supply within the organization [18]. Workforce issues with long-run equilibrium is significant in HRP areas where the most benefits will be achieved and be creative in developing strategies of workforce activities [14]. Once the issue has been properly addressed, the forecasting performance of HRP improves considerably [19]. Thus, this paper starts with highlights issues that causes local workforces are uninterested in Malaysian construction industry.

The numbers of local workforce become a problematic due to the lack of local workforce participation in Malaysian construction industry [6]. Local workforces are uninterested to join the construction industry because of the low wages [20]. The low wages are not sufficient to support majority of local workforce life and the wages given is not erratically for every month which depends to construction projects [8]. Hence, the problem highlighted is concerned with the wage system offered to local workforce for providing construction operation.

Educational change has affected the inflow of local workforce in Malaysian construction industry [9]. Commonly, most society sees the labors in the construction industry as a lacks prestige and low class [9]. Therefore, local young generations are seeking higher education for secure a more lucrative profession and consequently live a better life than their parents did.
Another important issue to be discussed is occupational safety issue [20]. Accidents on construction sites are very common and everybody accept it as an unavoidable feature of the industry [9]. Thus, accidents had tarnished the image of construction industry besides being labelled '3D images' which referred to dirty, dangerous and difficult. The proper training on safety and health training plays a significant role in the enhancement of safety in the construction [21]. However, the awareness level of contractors for such training is not satisfactory.

Besides that, temporary employment status as a labor causes the lack of participation by local workforce in construction industry [22]. Temporary employment status means that the majority of labors enjoy little or no social protection (income security or social security) [22]. Local workers seek a permanent job combining with the permanent wages and insurance protection as a guarantee to their life for the future [20]. In addition, the accommodation was provided by employer (contractor) is less conducive to the average Malaysian labors [23]. The reason also contributed to local workers shying away from the construction sector and considers employment in the construction sector as not dignified enough. There are also differences in the changes of development in Malaysia [8]. Ten years ago, most of the Malaysians were participated in construction industry to support the construction operation [24]. Currently, there are varieties competitive in other sectors such as agriculture; manufacturing; services and plantation which required big numbers of workforce to provide the operations [25]. Meanwhile, the numbers of local workforces are unaccommodating to provide the operations. Therefore, the raising demands on foreign labors to support the changes of situation.

As claimed by Tulacz [26], competition, globalisation, technological innovations, varying market and other factors occurrence affect the labor supply. With these conditions, there is need for intensive planning. The essence of HRP is the presence of a concrete plan of getting the right people particularly the employees as well as coaches in the given right place and time [27]. Hence, the fragmentation and dynamism need to integrate a wide range of good HRP practices [1]. The intention means the practices of HRP is not static but should respond to internal or external to the organization [28].

\section{HUMAN RESOURCE PLANNING (HRP)}

The benefits of conducting HRP are many and varied [29]. It allows organizations to restructuring, reducing or expanding their workforces [30]. HRP is concerned about analyzing of current workforce and extending the analysis to identify the future skills and competencies needed to deliver in the organizations [31]. Furthermore, HRP is not only static to the process but it also concern to the planning that responds to the changing circumstances, either internal or external changes [32][33]. Thus, in context of this research, there are required to determine the appropriate factors influencing HRP for local workforce in construction industry. 
In the field of construction work have developed specific theories regarding the use of human resources in successful construction operations [24]. For instance, HRP is use to make major demands on local labor markets successfully by improving the utilization of workforce and match them with future organizations objectives [34]. Thus, HRP is an essential portion in managing human resource within a diversifying construction nature [24]. Any organization including construction (main contractor, consultant or developer) needs to analyses current and future markets in order to ensure the right number of people with the required skills in the organizations [35]. Keel [13] emphasized that HRP should considered factors that might have significant impact on the size and kind of workforce that will be needed in the future. Therefore, leaders and human resource managers is required to conduct internal and external scanning to identify workforce trends in a proactive manner [14]. However, construction organization in Malaysia does not have a comprehensive HRP system in the organization planning. Hence, a wide range of literature is reviewed to identify factors influencing HRP for construction industry. For the purpose of this research, these factors can be categorized into two categories; internal and external factors.

\section{A. Internal factors}

The findings from the previous research show that the internal factors are controlled by the organization [36]. This can be characterized by at least six interrelated factors as listed in Table I.

TABLE I

INTERNAL HRP INFLUENCING FACTORS

\begin{tabular}{|c|c|}
\hline $\begin{array}{l}\text { Internal } \\
\text { Factors }\end{array}$ & Description \\
\hline $\begin{array}{l}\text { Organization } \\
\text { Strategy }\end{array}$ & $\begin{array}{l}\text { - Financial strength is a strategic asset in the } \\
\text { organization to reach ingenious strategic } \\
\text { plans [37]. } \\
\text { - The traditional philosophy of construction } \\
\text { planning placed a great emphasis on the } \\
\text { ability to plan and execute projects [38]. } \\
\text { - Two points in handling manpower at } \\
\text { construction sites; allocate manpower } \\
\text { whether to subcontract or to have a directly } \\
\text { employed labor force and the allocation of } \\
\text { directly employed manpower will depend } \\
\text { on the needs of the various projects [39]. } \\
\text { - The imbalance of managers at operative and } \\
\text { strategic level makes the strategic decision } \\
\text { hard to make for workforce planning [40]. }\end{array}$ \\
\hline $\begin{array}{l}\text { Organization } \\
\text { Changes }\end{array}$ & $\begin{array}{l}\text { - A small organization in the embryonic stage } \\
\text { may not have an appropriate planning [41]. } \\
\text { A need for planning is felt when the } \\
\text { organization enters the growth stage likes } \\
\text { layoff, retrenchment and retirement. } \\
\text { - The role of construction firm components } \\
\text { requires high flexibility commitment [42]. } \\
\text { - Labors commitment and personnel behavior } \\
\text { absolutely impact to construction } \\
\text { organization target [43]. For instance, the } \\
\text { limited time to stay in Malaysia gives a } \\
\text { chance to foreign labor to work hard and } \\
\text { consigns money to their family. }\end{array}$ \\
\hline
\end{tabular}

\begin{tabular}{|c|c|}
\hline $\begin{array}{l}\text { Organization } \\
\text { Culture }\end{array}$ & $\begin{array}{l}\text { - The culture of construction in the U.K was } \\
\text { influenced by its young, male and white } \\
\text { workforce [44]. } \\
\text { - Training initiatives are an important tool in } \\
\text { cultivating a desired culture [45]. } \\
\text { - Most construction companies at U.S are } \\
\text { dominated by a strong clan culture like an } \\
\text { extended family; emphasize teamwork, } \\
\text { participation and consensus; have labors } \\
\text { with a high level of loyalty; and emphasize } \\
\text { human development [46]. } \\
\text { - People in the construction industry are like } \\
\text { the clan culture. Individuals are rewarded } \\
\text { when the financial result is good or new } \\
\text { market shares have been won [47]. } \\
\text { - In Malaysia, culture of construction industry } \\
\text { was influenced by male of foreign labors } \\
\text { that local refuses to do [6]. }\end{array}$ \\
\hline $\begin{array}{l}\text { Leadership } \\
\text { and } \\
\text { Experience }\end{array}$ & $\begin{array}{l}\text { - Two-way communication helps to build } \\
\text { confidence and motivation of labor [48]. } \\
\text { - Majority of the construction manager felt } \\
\text { that they should consider suggestion and } \\
\text { ideas from the labors but they controlled the } \\
\text { decision making process [49]. } \\
\text { - Leader should focus on tasks and } \\
\text { relationships between labor and supervisor } \\
\text { [50]. } \\
\text { - Leaders influenced on labor motivation, } \\
\text { value and aspirations which subsequently } \\
\text { influence labor attitudes and behaviors [51]. } \\
\text { - The use of authority and punishment was } \\
\text { rated among the lowest of leadership } \\
\text { behaviours in the construction firms [52]. } \\
\text { - Leadership effectiveness is necessary to } \\
\text { understand an effort to inspire employees } \\
\text { and thus achieve organizational goals and } \\
\text { objectives [53]. }\end{array}$ \\
\hline Empowerment & $\begin{array}{l}\text { - Empowerment is encourage an } \\
\text { organizational learning and rethink the way } \\
\text { to do things; such as strategic alliance } \\
\text { formation and embracing a work } \\
\text { environment [54]. } \\
\text { - Empowerment of labor in completing his } \\
\text { job task because he has information, skill, } \\
\text { knowledge, experience and power [11][55]. }\end{array}$ \\
\hline $\begin{array}{l}\text { Nature of } \\
\text { Work }\end{array}$ & $\begin{array}{l}\text { - HRP is effectively in dealing the nature of } \\
\text { job to attain the organization mission [56]. } \\
\text { - HRP is the effective matching of the nature } \\
\text { of work with employee performing the task } \\
\text { [41]. } \\
\text { - The construction industry being a fearful if } \\
\text { the majority of manpower is manipulated by } \\
\text { foreign labor [20]. } \\
\text { - The task to be performed at construction } \\
\text { site is more nature and need a physical } \\
\text { durable [6]. }\end{array}$ \\
\hline
\end{tabular}

\section{B. External factors}

External factor of HRP is a macro factor influenced on HRP and cannot be controlled by the organizations [57]. Four elements of external factors influencing HRP as shown in Table II. 
TABLE II

EXTERNAL HRP INFLUENCING FACTORS

\begin{tabular}{|c|c|}
\hline $\begin{array}{c}\text { External } \\
\text { Factors }\end{array}$ & Description \\
\hline Legislation & $\begin{array}{l}\text { - Government law and regulations is a } \\
\text { powerful external factor which affects } \\
\text { organizations directly the federal regulations } \\
\text { activities, policies and programs [24]. } \\
\text { - Health insurance is a direct benefit to labor } \\
\text { in term of improved health [58]. Labors will } \\
\text { refuse to change jobs if they have pre- } \\
\text { existing medical conditions and fear losing } \\
\text { their medical coverage. } \\
\text { - In Malaysia, government plans to increase } \\
\text { the levy on foreign labor to reduce the } \\
\text { dependency on foreign labor [59]. }\end{array}$ \\
\hline $\begin{array}{l}\text { Economic } \\
\text { Changes }\end{array}$ & $\begin{array}{l}\text { - Economic forces influencing in growth or } \\
\text { decline of gross domestic product and } \\
\text { increases or decreases in inflation, interest } \\
\text { rates and exchange rates [60]. } \\
\text { - The economic that Malaysia has seen for } \\
\text { last decade is one of the leading causes of } \\
\text { the worker shortage [61] } \\
\text { - The low skills job is similarly with the low } \\
\text { wages [59]. } \\
\text { - In Malaysia, there are perhaps a low wage } \\
\text { needs to be increase in order to retain them } \\
\text { in construction industry and reflecting with } \\
\text { the nation economic [6]. }\end{array}$ \\
\hline $\begin{array}{l}\text { Technological } \\
\text { Changes }\end{array}$ & $\begin{array}{l}\text { - A constantly changing marketplace, } \\
\text { technology has moved to the forefront for } \\
\text { advancement potential in the construction } \\
\text { industry [62]. } \\
\text { - The employments of prefabricated } \\
\text { components, large forms, and high-strength } \\
\text { concrete are lead to considerable cost } \\
\text { savings and price reduction [38] } \\
\text { - The most part of construction projects are } \\
\text { constructed in situ and manpower is } \\
\text { important to provide the construction } \\
\text { operation [1]. } \\
\text { - In some cases, company may retain existing } \\
\text { employee and teach them the new } \\
\text { technology or remove existing people and } \\
\text { appoint new employees [19]. }\end{array}$ \\
\hline $\begin{array}{l}\text { Demographic } \\
\text { Changes }\end{array}$ & $\begin{array}{l}\text { - Workforce demographics provide necessary } \\
\text { baselines such occupations, grade level, } \\
\text { race, gender, age, length of service, and } \\
\text { retirement eligibility [63]. } \\
\text { - The changing demographic changes the } \\
\text { abilities, skill, interests, and values of } \\
\text { tomorrow's workforce [57]. } \\
\text { - Demographic change reduced the flow of } \\
\text { younger workers who have typically } \\
\text { provided much construction site labor [64]. } \\
\text { - The changing profile of the workforce in } \\
\text { terms of age, gender participation, literacy, } \\
\text { technical inputs and social background has } \\
\text { implications to HRP [11]. } \\
\text { - A number of people retire every year and a } \\
\text { new batch of graduates with specialization } \\
\text { turns out every year will change the } \\
\text { appointment or the removal in the company } \\
\text { [19]. }\end{array}$ \\
\hline
\end{tabular}

\section{METHODOLOGY}

Based on the literature review, the measures of HRP influencing factors for local workforce supply in the construction industry is indistinct in context of Malaysian practices. Therefore, semi structured interviews were conducted to explore the current practices of HRP influencing factors for local workforce supply in Malaysian construction industry. It also captures the current issues of local workforce in Malaysian construction industry. This method more flexible that is allows greater spontaneity and adaptation of the interaction between the researcher and the respondents [65]. Thus, respondents have the opportunity to respond more elaborately and in greater detail compared to survey questionnaire [65].

\section{A. Respondents}

The target of semi structured interviews was industry experts who had experience in conducting HRP in the construction industry and who are currently holding managerial positions in aspect of construction management. Two types of respondents: government and non-government organization (NGO) were selected to discuss current issues of local workforce in Malaysian construction industry and practices of HRP influencing factors for local workforce supply in Malaysian construction industry. Local government in Malaysia operates on the principles and perform as specifically enumerated in its various acts and by laws include all aspects such as: environmental, public (amenities, health and cleansing), social and developmental [66]. NGO are self-governing, independently financed organizations and societies that assign themselves specific roles, issues or disciplines paralleling governmental or ingovernmental organizations that have similar mandates [67]. Therefore, both perspectives are required to study the current situation of HRP in Malaysian construction industry. Semi structured interviews were employed with 10 respondents, three government and seven NGO. A purposive sampling method was used to select the respondents based on operational construct [68]. Seven of the 10 respondents were project managers, and three were directors of construction organizations. The respondents in these interviews had over five year's tenure with their organizations, and had a variety of professional and organizational backgrounds.

\section{B. Materials}

Materials used for recruiting and screening respondents included the invitation to participate letter and the informed consent. Approval of the human subject's protocol (invitation and informed consent) was obtained via email from all respondents. The interview questions are divided into two sections: (1) Current issues on local workforce in the construction industry and (2) Current practices of factors influencing HRP in the construction industry. Ten determinants of factors influencing HRP were raised to all organizations. Internal factors: (i) strategy of organization; (ii) organization changes; (iii) organization culture; (iv) nature of work; (v) leadership and experiences; (vi) empowerment of labor; and external factors; (vii) legislation; (viii) economic changes; (ix) technologies changes; and (x) demographic changes. To conduct the interview sessions, a 14 questions interview 
guide was prepared and tested with both peers and a trial respondent. This interview guide minimized bias, by providing a basis for a consistent sequence and approach to interviews, and adopted a consisted wording of the applicable questions. This interview guide also served as the form for collecting respondent's personal information, and for collecting specific notes during the interview.

\section{Procedure}

Respondents took part individually at their respective organizations and the interviews were scheduled for 45 to 60 minutes. They were asked to read the description of the research which allowed for the respondents to ask any questions to clarify the nature of the study or their expectations. Respondents agreed and understood that they could refuse to answer any question and terminate the interview at any time. Respondents were then asked a series of open-ended questions in a semi structured format from the interview guide. Respondents were encouraged to describe situations in significant detail, and were often followed by additional questions to probe for detailed explanations and each was later transcribed for use in analysis of respondents' responses.

\section{Data Analysis}

Interviewees were reflecting their experiences and knowledge on the current issues of local workforce and HRP practices in Malaysian construction industry. The researcher starts coded the result with the assistance of the Matrix table. It was divided into columns and rows where represented factors and description from each respondent. The coding of the transcribed data to ensure the results was easy to use and understand at end of this research. The researcher also made minor changes, which involved omitting words from some of the interview excerpts without affecting their meaning, in order to produce a more concise statement that would assist readers to understand it [62].

\section{RESULTS AND FINDINGS}

Semi-structured interviews were conducted to investigate the current issues of local workforce and the practices of factors influencing HRP for local workforce supply in Malaysian construction industry. Thus, the interview results are divided into two sections:

\section{A. Current Issues}

12 elements were mentioned as broadly current issues towards local workforce in Malaysian construction industry:

- Uncomfortable environment. Employers explained that un-comfortable environment such as: hot weather; un-healthy environment; and no air conditioner causes local workforces are un-interested with construction industry.
- '3D images'- dirty, dangerous and difficult. Employers labelled construction industry as heavy work and exposed to accident at construction site. Accidents on construction sites are very common and everybody accepts it as an unavoidable feature of the industry [11]. Thus, accidents had tarnished the image of construction industry besides being labelled ' $3 D$ images' which referred to dirty, dangerous and difficult. Besides that, a construction task is difficult because need to provide heavy work such as: bricklaying; plastering; tiling; bar-bending; concreting; and formwork.

- Low wages. Employers mentioned that the low wages cause local workforces are uninterested with construction industry. The wage level is not applied properly according to the skill labor but it depends on competence of employer to payoff labor [7][13].

- Temporary work. Employers also stated that labor force in the construction industry is temporary work. Our local workforce required a permanent job and wage in order to maintain their economy.

- Lack prestige and social behaviours. In addition, employers agreed that the lacks prestige to employ as labor in the construction industry cause local workforces is uninterested with construction industry. This results regarding to the society behaviour toward labor work is not dignified enough because it is view as a low status job [22].

- Young generations seek higher education. Employers mentioned that the lack of local workforce in the construction industry is due to education changes for a nowadays. Young generation seeks a higher education to have a lucrative life better than their parents did [9].

- No insurance protection for labor. At the same time, labors are preferable an insurance protection as a warranty to their life whenever they are injured or accidentally. EPF or SOCSO is qualified enough if employers are no providing insurance protection to them.

- Occupational safety. The safety issue is almost worried among people to be involved as a labor in construction industry [9][21]. People need to keep away their feeling about the safety in the construction industry because construction personnel's always remind labors to use the safety tool to avoid any accidentally.

- Development and technologies changes. There are many job opportunities within other industries that easier than construction tasks. In the construction industry, manpower required for done a wet trade job such bricklaying, plastering, tiling, bar-bending, concreting and formwork.

- Difficult to get permission for leave: High commitment required by labor at construction site in order to complete the construction operation. It is become difficult onto employer to allow their labor for leaved.

- Un-predictable work. Sometimes labors are required to working overtime in order to achieve an 
expectation project. However, employer stressed that local labors are un-willing to work overtime.

- Weakness on organizations strategies. Employer needs to study and analyze their HRP processes to retain and attract more local labors in the construction organization [24]. Some of organizations are not planning their HRP smoothly causing labors are quit from their job.

With these issues, there is need intensive HRP for future local workforce supply to prevent the decline numbers of local labor in Malaysian construction industry. The practices of HRP are not static but should respond to internal or external to the organization [28]. Hence, this research needs to integrate a wide range of good HRP practices.

\section{B. Current practices of HRP in construction industry}

Ten determinants of factors influencing HRP were raised to all organizations for local workforce supply in Malaysian construction industry. Internal factors such as: (i) organization strategy; (ii) organization changes; (iii) organization culture; (iv) nature of work; (v) leadership style and experiences; (vi) empowerment; and external factors; (vii) legislation; (viii) economic changes; (ix) technologies changes; and (x) demographic changes. All of determinants are significance to predict the reasonable local labor required for construction project as shown in Table III and Table IV.

TABLE III

INTERNAL HRP INFLUENCING FACTORS (CURRENT PRACTICES)

\begin{tabular}{|c|c|}
\hline $\begin{array}{l}\text { External } \\
\text { Factors }\end{array}$ & Description \\
\hline $\begin{array}{l}\text { Organization } \\
\text { Strategy }\end{array}$ & $\begin{array}{l}\text { - Determine the ability and skill of labor. } \\
\text { - Train labor with the basic skill of } \\
\text { workmanship. } \\
\text { - Analyze the whole of financial company. } \\
\text { - Consider labor opinion and provides a } \\
\text { complete safety tool. } \\
\text { - Determine the long term of labor } \\
\text { requirement such as: insurance and health } \\
\text { facilities. }\end{array}$ \\
\hline $\begin{array}{l}\text { Organization } \\
\text { Change }\end{array}$ & $\begin{array}{l}\text { - Employers decided to terminate and hire a } \\
\text { new labor if labors are irresponsible to task. } \\
\text { - Un-balance management contributed to the } \\
\text { financial problem. } \\
\text { - Un-skill labor impacted to organization } \\
\text { target. } \\
\text { - Un-sufficient of labors force impacted to } \\
\text { construction operation. }\end{array}$ \\
\hline $\begin{array}{l}\text { Organization } \\
\text { Culture }\end{array}$ & $\begin{array}{l}\text { - Organizations are not distinguishing man or } \\
\text { female involvement. } \\
\text { - Foreign labor were supported the lack of } \\
\text { local labor. } \\
\text { - Employers concerns with the punctuality of } \\
\text { labor to complete their task. } \\
\text { - Good relation among employers and all } \\
\text { labor show a good image for organization. } \\
\text { - High cost will be spent by company to send } \\
\text { numbers of labors to attend training course. }\end{array}$ \\
\hline Empowerment & $\begin{array}{l}\text { - Labors have a voice for un-satisfied of their } \\
\text { acceptance. } \\
\text { - Labor able to do their own activities after } \\
\text { working hour. }\end{array}$ \\
\hline
\end{tabular}

\begin{tabular}{l|l}
\hline & $\begin{array}{l}\text { - Major factors of labour empowerment are } \\
\text { skill knowledge and experiences. } \\
\text { - Labors are able to give an opinion or inform } \\
\text { any problems. }\end{array}$ \\
\hline Wature of & $\begin{array}{l}\text { - Un-fixed salary and un-predictable work. } \\
\text { - Pressures under employer directive. } \\
\text { - Labors are required to find another task } \\
\text { after project completion. }\end{array}$ \\
- Un-healthy environment such dirty, \\
dangerous, and the poor accommodation. \\
- There are no insurance protections provided \\
by their employer. \\
- There are more competitive of job \\
opportunities in other industry.
\end{tabular}

TABLE IV

EXTERNAL HRP INFLUENCING FACTORS (CURRENT PRACTICES)

\begin{tabular}{|c|c|}
\hline $\begin{array}{c}\text { External } \\
\text { Factors }\end{array}$ & Description \\
\hline Legislation & $\begin{array}{l}\text { - The cooperation between the education } \\
\text { institution and construction organization } \\
\text { will enhance service provision. } \\
\text { - Employers applied a standard procedure in } \\
\text { order to employ foreign labor. } \\
\text { - The wages level reflects to the skill of } \\
\text { labors. } \\
\text { - Labor should be an educated group that } \\
\text { learns the skill from education institution. } \\
\text { - Labor should be placed under the } \\
\text { government project to ensure they are } \\
\text { continually able to generate their economy. } \\
\text { - A strong of standard safety should be } \\
\text { provided during in construction site. } \\
\text { - Women are not supported to be involved as } \\
\text { labor. } \\
\text { - Employer should provide good facilities } \\
\text { such insurance protection and health } \\
\text { facilities. }\end{array}$ \\
\hline $\begin{array}{l}\text { Economic } \\
\text { Changes }\end{array}$ & $\begin{array}{l}\text { - High market demand toward skilled labor. } \\
\text { - The strength growth of Malaysian economy } \\
\text { required the numbers of qualified worker. } \\
\text { - The growth economy may impact to labors } \\
\text { in order to support their daily expenditure } \\
\text { due to the price increase of daily products. } \\
\text { - The wage system must according to the } \\
\text { current development of the nation economy. } \\
\text { - The weak global economic cause the } \\
\text { organization is unable to achieving the } \\
\text { projected growth rate or may be no project } \\
\text { target. }\end{array}$ \\
\hline $\begin{array}{l}\text { Technology } \\
\text { Changes }\end{array}$ & $\begin{array}{l}\text { - Majority of the job task at construction site } \\
\text { required labor force especially for "'Wet } \\
\text { Trade Work', } \\
\text { - The company may retain and train existing } \\
\text { labor or remove and appoint new labor } \\
\text { affect of technology change. } \\
\text { - Skill of labor must be parallel with } \\
\text { technology change. }\end{array}$ \\
\hline
\end{tabular}




\begin{tabular}{l|l}
\hline & $\begin{array}{l}\text { - Improvement of technology able to assist } \\
\text { and accelerate a work site progress. }\end{array}$ \\
\hline $\begin{array}{l}\text { Demographic } \\
\text { Changes }\end{array}$ & $\begin{array}{l}\text { - Among people has high education for a } \\
\text { better salary. } \\
\text { - Male labors were dominated in the } \\
\text { construction industy. } \\
\text { - Young generations are rarely to participate } \\
\text { as a labor force. } \\
\text { - A poor family has no choice to involve as a } \\
\text { labor force. } \\
\text { - An attitude among people toward } \\
\text { construction work is not respectfully } \\
\text { enough. } \\
\text { - There are more competitive with other job } \\
\text { opportunities that more easily and more } \\
\text { benefits to job seekers. }\end{array}$ \\
\hline
\end{tabular}

Every construction companies analyzed whole of financial company; whether current financial affects current workforce or current financial affects future workforce. These finding are consistent with Warsawski [38] which considered the financial strength of a company to be an important strategic asset. When employers decided to terminate and hired a new labor, organization plan need to be change. Thus, company need to consider the financial budget to paid labor; strategy to promote the vacancy job; and company needs a recruitment and selection process. One possible explanation might be involved with Azman et al. [44], labor commitment and personnel behaviour absolutely impact to the organization target. Furthermore, unsufficient of manpower (labor) to provide the construction operation causes organization change. Thus, organization planned to import foreign labor to replace the lack of local labor in construction industry.

The system held in construction industry is not distinguishing man or female involvement. In addition, the organization culture in construction industry is influenced by the way of leader to handling the organization. Moreover, each labor is required to be teamwork in order to assisting leaders to organize and managing the organization [47][48]. On the other hand, a good relation among employers and every worker level show a good image for those organizations. Thus, there are no issues that the culture in organization is impact by level of designation.

The construction industry in Malaysia is known as ' $3 \mathrm{D}$ images- dirty, dangerous and difficult' [9]. Labors are exposed to high risk which accidentally occurred. Similar to Hong [6], heavy work has been done as a labor at construction site. Today's, there are more competitive of job opportunities in other industry that not required heavy work such as work at supermarket and factory.

It is not a matter about the nature of work as a construction workforce, but factors such as the pressure under leader or employer directive which most employer need to achieved their expectation projects. Labors are responsibilities to handling work at construction site to make sure the work progress as the organization planning [52]. Hence, a good communication and relationship between leader and labor was the most reliable predictor of labor satisfaction and winning labor trusty toward construction organization. Two-way communication of both the leaders and labor although the leader still controls decision making [49]. Thus, labors are coherent to work in the organization for a long term objectives. The empowerment of labor to completed his job task because he has information, skill and knowledge [56]. In other things, labor who has high experiences is high market demand because they able to produce a high quality of productivity without a fully supervision.

Employers were asking about the current, new or anticipated legislation will affect the construction workforce. The encouragement of building cooperation between the education institution and construction organization will enhance service provision. The collaboration between institutes of higher learning and industry also increase local talent in Malaysia [59]. Meanwhile, employers emphasised that construction company should applied a standard procedure in order to employ foreign labor. Thus, government is able to control the actual numbers of foreign labor and giving a chance of local labor opportunities. Furthermore, employer should provide good facilities in order attract or retain workforce in his organization such providing the health facilities among construction workforce. Health insurance also as a direct benefit to labors to improved healthy [58].

There is now growing evidence that most economies have passed their troughs and in the short term recovery could prove surprisingly strong. In 2010, there are many building need to be construct according to 'Malaysia Planning at Ten Decades'. Thus, it gives a chance to among labors to generate their economic. However, the growth economy may impact to the lower income group. Labors are unable to support their daily expenditure due to the price increase of daily products. Hence, the wage system of the work labor must according to the current development of the nation economy. A global economic conditions has necessary to enable Malaysia achieve the projected growth rate [61]. However, the weak global economic cause the organization is unable to achieving the projected growth rate or may be no project target.

For current practices, construction industry needs an improvement technology to supports the lack of manpower to provide the construction operation. Majority of the job task at construction site still require manpower to assists the construction operation [1]. Furthermore, improvement of technology impact to production target; able to assist and accelerate a work site progress in order to achieve expectation project. For example, the employments of prefabricated components, large forms, and high-strength concrete are lead to considerable cost savings and price reduction [32].

There are a lot of changes for the education level today. Demographic change reduced the flow of the younger workers who have typically provided much construction site labor [64]. Young generations are seeks a high education for a lucrative professions and better life than their parents did. In addition, majority of labor is dominated by male worker because they able to do a heavy work in construction projects. As contented by London et al. [63], construction industry is influenced by 
gender participation. In line with Kaur [11], background of family may influence to construction workforce. For instance, a poor family has no choice to involve as a labor in order to generate their economy.

To sum up, these results demonstrates that factor influencing HRP play a critical role in designing HRP for local workforce supply in construction industry in order to develop local labor confidence toward organizational commitment. Clearly, factors influencing HRP listed every possible about the internal and external changes and how those changes will affect the requirements need by local labor in construction industry.

\section{CONCLUSIONS}

The purpose of this study is to explore the current practices of HRP influencing factors for local workforce supply in Malaysian construction industry. It also captures the current issues of local workforce in Malaysian construction industry. Traditionally, employers understand that labor represent under organization to assists the construction operation at the construction site. Thus, employers heavily focused on the goal to completing construction project due to the duration of project. Currently, employers gave a greater emphasis to labor interest and the process of handling and managing local labor in the organization.

Although this study reports on the use of factors influencing HRP towards local workforce supply in the construction industry in general, and Malaysian construction in particular, this study has some limitations and the additional research areas. The current practices of HRP through semi structured interviews were used 10 perspectives of government and NGO organizations. Therefore, further research should be conducted in the large scope of respondents such as survey questionnaire about verifying the HRP implementation and scenario that goes as planned. We plan to use the industrypractitioner cooperation for further research. It is hoped that the findings from this research will provide some indication to the parties involved in Malaysian construction industry.

This study intended to resolve the circumstances, in which the lack of local workforce participation in Malaysian construction industry, through the current study of HRP implementation. In other words, it was found through the internal and external factors influencing HRP for local workforce supply in Malaysian construction organization that listed labours interest and their requirements. This study has its significance from the point of view that it is an attempt in an area in which there was no precedent research, both domestically and internationally.

\section{ACKNOWLEDGEMENT}

This research is supported by Universiti Tun Hussein Onn Malaysia, UTHM under project Fundamental Research Grant Scheme (FRGS) no. 0687.

\section{REFERENCES}

[1] M. Loosemore, A.R.J. Dainty, H. Lingard, "Human resource management in construction project: strategic and operational approaches", London: Spon Press, 2003.

[2] Z. Abdullah, "The Effect of Human Resourc Management Practices on Business Performance Among Private Companies in Malaysia”, Business and Management, vol. 4, no. 6, pp. 65-72, 2009.

[3] V.C. Duffy, G. Salvendy, "Concurrent engineering and virtual reality for human resource planning", Computer in Industry, vol. 42, no. 2, pp. 109-125, 2000.

[4] N. Busing, I. Gold, "Important Contributors to Health Human Resource Planning in Canada", Health Papers, vol. 9, no.2, pp. 25-29, 2009.

[5] J.W. Boudreau, P..M. Ramstad, "Talentship and the New Paradigm for Human Resource Management: From Professional Practices to Strategic Talent Decision Science", Human Resource Planning, vol. 28 , no. 2, pp. 17-26, 2005.

[6] C.K. Hong, "Response letter: pengurusan pekerja di tapak bina", Kuala Lumpur: CIDB, 2010.

[7] N. Zamzila, "Pengambilan pekerja asing dalam industri pembinaan”, M. S. Thesis: Universiti Teknologi Malaysia, 2005.

[8] N.A. Othman, "Pengambilan buruh asing dalam industri pembinaan di Malaysia", M.S. thesis: Universiti Teknologi Malaysia, 2003.

[9] CIDB. "Construction industry master plan Malaysia 2006-2015", Kuala Lumpur: CIDB, 2007.

[10] N. Vareta, "Importance of Human Resource Planning in Organizations", $\quad$ www.oppapers.com/essays/Hr-Planning/427456, 2010.

[11] S. Kaur, "Human resource planning: nature and need", Journal Management, vol. 2, pp. 259-298, 2006.

[12] W.M.J. Wong, "Forecasting manpower demand in the construction industry of Hong Kong", Ph. D. Thesis: The Hong Kong Polytechnic University, 2006.

[13] J. Keel, "Workforce planning guide", Texas: State Auditor's Office (SAO) report, pp. 06-704, 2006.

[14] P.A. Cotten, "Seven step of effective workforce planning", West Tower, Washington: IBM Center for the Business of Government, 2007.

[15] S. Randy, S. Loretta, W. Bryan, "A skilled and educated workforce: an assessment of the number and type of higher education and training credential required to meet employer demand", US: Washington Higher Education Coordinating Board (WHECB), 2006.

[16] Y.H. Chiang, E.H.N Chan, S. Sharma, "The construction sector in asian economies", New York, London: Spon Press, 2004.

[17] M.F. Helmi, "Had pekerja asing kepada 1.5 juta", Retrieved May 7, 2010, from http://www.utusan.com.my.

[18] B.D. Deborah, W. Sheila, M.K. Kristin, R.M. Amanda, R. Mike, H. Susan, "Strategic workforce planning guidebook", Virginia:Country of Fairfax, 2003.

[19] H.K. Paul Ho, "Forecasting construction manpower demand by Gray model", Journal of Construction Engineering Management, vol. 136, no.12, pp. 1299-1305, 2010.

[20] S.S. Salleh, "Causes of poor participation of local workers in Malaysia construction industry and strategies for improvement", M.S. Thesis: Universiti Teknologi Malaysia, 2008.

[21] T.M. Toole, "Construction site safety roles", Journal of Construction Engineering and Management, vol. 12, no. 5, pp. 203-210, 2002.

[22] ILO, "The construction industry in the twenty first century: its image, employment prospects and skill requirements", Geneva: International Labor Organization (ILO), 2001.

[23] CIDB. "Skill accreditation for construction site personnel", Kuala Lumpur: CIDB News. Reading, issue June 2, 2000.

[24] T.H. Leng, "Human resource planning and human resource development in construction", M.S. thesis: Universiti Teknologi Malaysia, 2005

[25] M.B. Faiz, "Analisis kekurangan tenaga mahir dalam industri .pembinaan di Malaysia”, M.S. thesis: Universiti Teknologi Malaysia, 2007.

[26] Tulacz, Gary J, "The top 400 contractors: business before celebrations", Engineering News Record, vol. 224, no.1, pp. 82 93, 2000 
[27] G. Maycunich, "Beyond the learning organization: HR strategy and planning", Cambridge: Perseus Books, 2000.

[28] IES, "Workforce planning the wider context: a literature review", Brighton, UK: Institute for Employment Studies (IES), 2003.

[29] D.A. Decenzo, S.P. Robbins, "Human resource management: concept and application", New York: John Wiley, 1999.

[30] Abhishek, "Factors affecting human resource planning in an organization", Retrieved March 3, 2010 from http://hrmba.blogspot.com/2009/11/factors-affecting-humanresource.html.

[31] U.S. Department of Energy, "Workforce Planning Guide", U.S. : DOE, 2005.

[32] G. Johnson, "Strategic change and the process", Journal Management, vol. 26, no. 3, pp.513-563, 2000.

[33] S.G. Brandenburg, C.T. Haas, R.L. Tucker, "Strategic Management of Human Resources in Construction", Journal of Management Engineering, vol. 22, no.2, pp. 89-96, 2006.

[34] N. Horkan, H. Elizabeth, "Workforce planning at Department of Transportation (DOT)", U.S. : Spring, 2000.

[35] R. Bledsoe, "Building successful organizations: a guide to strategic workforce planning", National Academy of Public Administration, 2000.

[36] C.B. Gupta, "Human Resource Management", New Delhi: Sultan Chand and Co, 1997.

[37] A. Warszawski, "Strategic Planning in Construction Companies", Journal of Construction Engineering and Management, vol. 23, no.1, pp. 1330-1402, 1996.

[38] R.J. Thomas, P. Cheese, "Leadership: experience is the best teacher", Journal of Strategy \& Leadership, vol. 33, no. 3, pp. 2429,2005

[39] I.M. Azreen, "Critical success factors for the construction organization", M. S. Thesis: Universiti Teknologi Malaysia, 2005.

[40] K. Gabriel, N. Pontus, "Strategy implementation in the construction industry", M. S. Thesis: Jonkoping International Business School, Swedish, 2007.

[41] M.H. Boyd, "Human Resource Planning: The Long and the short of it", Boyd Associates, pp. 9 -16, 2008.

[42] Mary, "The lived experience of managers during organizational change: a phenomenological study of one firm in the residential construction industry", $\mathrm{PhD}$ thesis: University of George Washington, 2008.

[43] I. Azman, A.R. Shaik, H.M. Som, M.N. Saludin, H.B. Mohamed, R. Nordin, N.F.A. Zainudin, "Relationship between leaders and follower as a predictor of organizational commitment and job satisfaction", Proceeding of national human resource management conference, vol. 1, no. 5, pp. 463-476, 2010.

[44] S. Barthorpe, R. Duncan, C. Miller, "The pluralistic facets of culture and its impact on construction", Property Management, vol. 18 , no. 5, pp. 335-351, 2000

[45] R. Rameezdeen, N. Gunarathna, "Organizational culture in construction: an employee perspective", The Australian Journal of Construction Economic and Building, vol.3, no.1, pp. 292-300, 2003.

[46] E.O. Yazic, D. Arditi, B.O. Uwakweh, "Organizational culture in U.S construction companies", Journal Management, vol. 6, no. 1, pp. 219-228, 2007.

[47] J. Nummelin, "Measuring organizational culture in construction sector-finnish sample", Journal of Construction Management, vol. 23, no. 1, pp. 215-225, 2007.

[48] C. Fraser, "The influence of personal characteristics on effectiveness of construction site managers", Journal of Construction Management and Economic, vol. 18, no. 1, pp. 29-36, 2000.

[49] S.R. Toor, G. Ofori, "Leadership for future construction industry: Agenda for authentic leadership", International Journal of Project Management, vol. 26, no. 6, pp. 620-630, August 2008

[50] K. Panthi, R.U. Farooqui, S.M. Ahmed, "An investigation of the leadership style of construction managers in South Florida", Journal of Construction Management and Economic, vol. 11, pp. 455-565, 2008

[51] H.S. Jenny, H. Ali, F.M. Shamsudin, "The role of leadership behavior in task performance and contextual performance", Proceedings of national human resource management conference, vol. 1, no. 5, pp. 454-462, 2010.

[52] Sammy, "Leadership Development in the construction engineering industry", M.S thesis: The University of Alabama, Tuscaloosa, 2010.

[53] A.T. Amin, A.B. Abu, "Towards assessing the leadership style and quality of transformational leadership: The case of construction firms of Iran", Journal of Technology Management, vol. 5, no. 3, pp. $245-258,2010$

[54] Gary D. Holt, Peter E.D. Love, L. Jawahar-Nesan, "Employee empowerment in construction: an implementation for process improvement", Team Performance Management: An International Journal, vol. 6, no. 3/4, pp. 47-51, 2000.

[55] Darlington, "Employee empowerment as an effective tool to increase administrative efficacy in the local government area of Umunneochi, Nigeria”, M.S. thesis: University of Walden, 2002.

[56] Susan, Randall, "Human Resource Planning: Challenges For Industrial/Organizational", American Psychologist Association, vol. 45, no. 2, pp. 223-239, 2001.

[57] R. Khurana, K. Kumar, P. Suklabaidya, "Macro level scenario of human resource planning. India", Indra Gandhi National Open University (IGNOU), pp. 19-28, 2008

[58] W.K. Jae, "Health insurance and workers retention in the construction industry", Ph. D thesis: University of Utah, 2007.

[59] A.A. Aziz, D.A. Razak, H. Kassim, Y. Huang, H.J. Kharas, M.J. Abidin, D. Quah, A. Sheng, Z.A. Yusof, S.N. Zefferys, "New Economic Model for Malaysia", Kuala Lumpur, Malaysia: National Economic Advisory Council (NEAC), 2010.

[60] M.S. Darshan, M. Vivek Chandar, N. Girish, N.M. Arunkumar, "Corporate planning and strategy in construction". National Institute of Construction Management and Research, p. 3-12, 2006

[61] N.Z. Zahidi, A.R. Afzanizam, "Malaysia: Bank Negara Malaysia Annual Report 2008- Making the Right Moves", Kuala Lumpur Malaysia: Malaysian Rating Corporation Berhad (MARC), 2009.

[62] L.G. Abraham, P. Chinowsky, "Critical success factors for the construction industry", Proceedings of first international conference on construction in the 21st century, United Kingdom. 2002.

[63] M. London, E. Bassman, J. Fernandez, "Human Resource Forecasting and Strategy Development: Guidelines for Analyzing and Fulfilling Organizational Need", West CT: Quorum Books, 1990

[64] E-CORE, "Strategy construction for research technology development (RTD)", Lozenberg: European Council for Construction Research, Development and Innovation (ECCREDI), 2005.

[65] N.K. Denzin, Y.S. Lincoln, "The sage handbook of qualitative research", $3^{\text {rd }}$ ed., Thousand Oaks, CA: Sage, 2005.

[66] S. Chee, S.N. Phang, "The Role of Residents, Non-Governmenta Organizations and Quasi-Public Agencies in Local Government in Malaysia", Tokyo: Comparative Studies of Public Administration, EROPA Local Government Centre, 1992.

[67] M. Shariff, "Role of non-governmental organizations (NGOs) in fish health management in the Asia-Pacific", In Health Management in Asian Aquaculture. [In: Proceedings of the Regional Expert Consultation on Aquaculture Health Management in Asia and the Pacific. Subasinghe, R.P., Arthur, J.R. and Shariff, M. (eds), p. 51-59. FAO Fisheries Technical Paper No. 360. Rome, FAO. p. 142, 1996]

[68] M.Q. Patton, "Qualitative Evaluation and Research Methods", $2^{\text {nd }}$ ed., Newbury Park, CA: Sage Publication, INC., 1990. 